\title{
Novel Designs Inspired from Egyptian Environment for Hotel Uniform.
}

\author{
Ayat I. Mohamed, Maha M.T. Eladwi, Rehab M. Kotb \\ Textile and Clothing, Faculty of Women for Arts, Science and Education, \\ Ain Shams University, Cairo, Egypt
}

\begin{abstract}
:
A uniform is a set of standard clothing worn by members of an organization while participating in that organization's activity. In this study the uniforms of hotel (coats, aprons, bows, trousers, etc.) were performed by using different materials (linen, gabardine and popline fabrics) available in Egyptian markets. There designs inspired from Nubia folklore. The fabrics used were biopolished using cellulase enzyme to improve their quality (fuzzing and pilling). Physicomechanical properties were measured. Dyeing of finished fabrics was carried out using reactive dyes.
\end{abstract}

Key words: uniform, cellulosic fabric, biopolishing.

\section{Introduction}

A Uniform is clothing of distinctive design worn by members of a particular group as a means of identification such as military uniform, navy uniform, prison uniform, work uniforms and services uniforms, school uniform Robison J. (2005). Hotel staff is the appearance of every hotel. People, working in the hotel, form the attitude of the clients to the hotel no less than the interior or the menu. The range of hotel garments can be modified according to specific size, color, logo, fabric and design specifications Nelson K. et al. (2000). The uniforms can be availed in embroidered designs and can be manufactured from different quality of fabric like Gabardine, popline and linen. Biopolishing is a finishing process that improves fabric quality by mainly reducing fuzziness and pilling property of cellulosic fiber by using cellulase enzyme Kiro M. (2011). Cellulase treatment of cellulosic fabrics is an environmentally friendly way of improving the property of the fabrics. Cotton washing with cellulase is thus a standard technique, providing an environmentally friendly process to achieve a desirable appearance and soft handle for fabrics.

Ramakrishnan A. et al. (2007).

In the textile industry, finishing stage is where the specific properties are imported into fabrics, changing their appearance and improving their resistance to water, chemicals, biological, physical, mechanical and general wear. Moreover, finishing of fabrics will provide several features producing multifunctional textile.

The selection of the appropriate dyes and dyeing processes for cellulose is based on numerous factors depending on the application for which the dyed cellulose fibers are to be used Anon (1996). Fiber-reactive dyes are the only dye class that forms covalent bonds with the hydroxyl groups of the cellulose substrate.

Corresponding author: Ayat I. Mohamed, Textile and Clothing depart. , Faculty of Women for Arts, Science and Education, Ain Shams University, Cairo, Egypt.

Email: Ayat bnan@ymail.com. Tel.: 01021575609, 01152862230. 


\subsection{Needed Elements in uniform design:-}

Depending on the type of hotel and the nature of work that the staff is involved in, uniforms could be simply utilitarian or highly attractive or a combination of both.

a) Ornamentation: The design of the garment based on functionality, visual and tactile impact to what extent does it serve an aesthetic purpose.

b) Practicality/Necessity: The protective or strictly is utilitarian qualities of a garment.

c) Communication/Identification: Uniforms indicate membership in a group or team.

d) Mutability / Reconfigurability: This element refers to how much the wearer can transform or customize a garment.

e) Off Body: the free movements of the staff throughout a hotel and work area with fitting design.

f) Light/Luminosity: This element refers to the modulation of light by or on a garment. Black clothing absorbs light. Elise D.C. (2000).

Nubia is a region along the Nile River, which is located in northern Sudan and southern Egypt.

Nubian Architecture: The walls of the house especially the façade were decorated with ornaments and paintings of flags, flowers, birds and animals as shown in figure.(1) Samiha A. (2012).

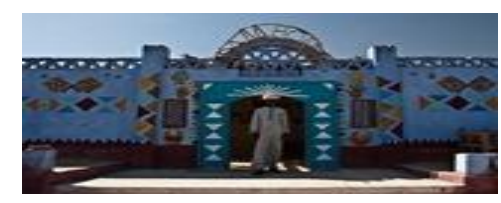

Figure (1): The decorative printed on wall and bawaba.

Color in the Nubian House: The exterior color scheme in the old Nubian houses reveals an earthy color scheme varying between yellow, brown, dark brown, white and yellow-grey, contrasts in saturation add interest without deformation of form as shown in figure (2). Diana K. et al. (2012).

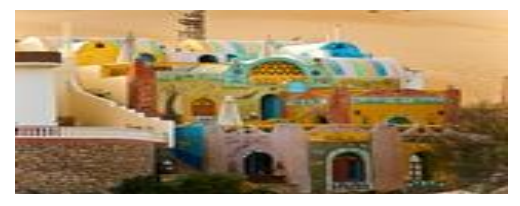

Figure (2): Nubian house colors.

Nubian handicrafts: The Nubians have unique handicrafts made of reeds and river palm leaves. These are often done in different colors and are very attractive and popular as shown in figure (3).

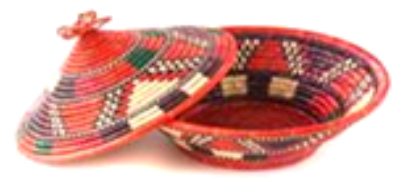

Figure (3): Nubian handicraft. 
Nubian Traditional Dressing: The Nubian woman dressing is unique especially among the women-"Gurbaba" worn beneath the dress or "Kamis Toub" is to cover the shoulders and head.

Other items of dressing are "Mendil", head scarf; "Ndala" is sandal for women and "Nila" for men. Women also wear "Bangil, Fidua, swar, suksuk"-assessorries-Bangels as shown in figure (4).

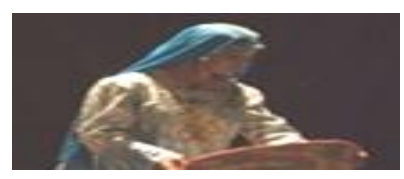

Figure (4): Nubian women dressing.

The Nubian man is normally dressed in "Kanzu" that means robe, tunic, or kaftan; it is a white or cream colored robe as shown in figure (5).

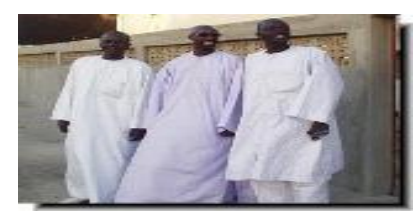

Figure (5): Nubian man tunics.

Nubian Wedding: The wedding ceremonies and festivities connected with marriage were among the most important public events in the social life of Nubians. The Dukhan and Henna day before the official Henna day the groom's sisters and friends go to a henna designer to paint their hands. After drying, the henna is washed off, placed their hands and feet over a hole in the corner of a dark and smoky room the women call the "dukhan" as shown in figure (6).

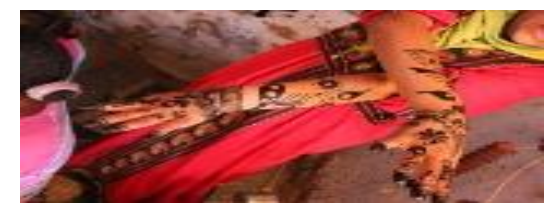

Figure (6): A girl exhibits her henna design.

Nubian wedding dress: The brides wedding outfit - A large colorful traditional Nubian garment known as a Gurbaba a white loose dress, a long sari- like cloth and sandals. On the day of the wedding, all of us men were dressed in the traditional Jalabeya, stark white textured cotton gowns and embroidered caps. Emberling G. (2011). 


\section{Materials and Methods:}

2.1. Materials: $100 \%$ woven cotton fabrics used; Popline and Gabardine and linen, fabrics

\begin{tabular}{|l|c|c|c|c|c|c|}
\hline Fabric types & $\begin{array}{l}\text { Produc } \\
\text { t No: }\end{array}$ & $\begin{array}{l}\text { Weave } \\
\text { Structure }\end{array}$ & Weight & Yarn count & Density & Bleaching \\
\hline $\begin{array}{l}\text { Blank } \\
\text { gabardine }\end{array}$ & 2790 & Twill $3 / 1$ & $265 \mathrm{~g} / \mathrm{m}^{2}$ & 1.7 tex ends & 90 ends/inch & $\begin{array}{l}\text { Half } \\
\text { bleached }\end{array}$ \\
\hline $\begin{array}{l}\text { Blank } \\
\text { popline }\end{array}$ & 2257 & Plain $1 / 1$ & $120 \mathrm{~g} / \mathrm{m}^{2}$ & 4 tex end & $\begin{array}{l}\text { 109ends/inch } \\
72 \text { picks/inch }\end{array}$ & $\begin{array}{l}\text { Half } \\
\text { bleached }\end{array}$ \\
\hline Blank linen & $1567 /$ & Plain $1 / 1$ & $207 \mathrm{~g} / \mathrm{m}^{2}$ & 7 metric end & 125 ends/inch & Bleached \\
\hline
\end{tabular}

properties shown in table (1).

Table (1): Fabrics properties.

2.2. Chemicals: Cellulase Enzyme used under the commercial name of Dinamex and Hydrogen peroxide $\left(\mathrm{H}_{2} \mathrm{O}_{2}\right)$ were used in bleaching process. The dyes used ME Red ME4BL (C.I Reactive Red 195 ) and Jakofix Yellow MERL (Reactive Yellow 145) are bifunctional groups dyes, Drimaren Blue CLBR (C.I. Reactive Blue 160) and Remazol Black B (C.I Reactive black 5).

2.3. Methods: Biopolishing was conducted using cellulase enzyme $(2 \mathrm{~g} / \mathrm{l})$ of the enzyme solution at a buffered $\mathrm{pH}$ of $4.5-5$ and at a temperature in the range of $45-60^{\circ} \mathrm{C}$ for $45 \mathrm{~min}$, finally tumble to dry. Reactive dyeing of fabrics were carried out using ME ${ }^{\circ}$ Red ME4BL $6 \%$ shade, Jakofix ${ }^{\circ}$ Yellow MERL 6\% shade, Drimaren Blue CLBR 6\% shade and Remazol Black B 10\% shade and their mixtures according to the manufacture instructions (Glauber's salt $\left(\mathrm{Na}_{2} \mathrm{SO}_{4}\right)$ - alkali $\left(\mathrm{Na}_{2} \mathrm{CO}_{3}\right)$ at $60^{\circ}-90^{\circ} \mathrm{C}$ for 1 hour) as shown in figure (7).

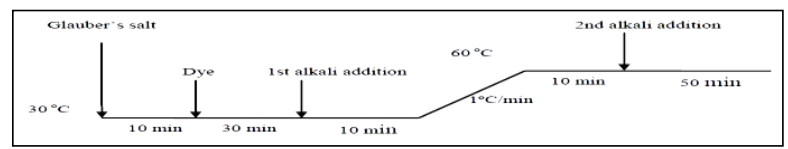

Figure (7): Reactive dyeing procedure.

2.4. Test Methods: The warp and weft yarn count of fabric were measured according to ASTM $D$ 3775 - 98,The fabric weight was measured according to ASTM Test Method D 3776- 96, The fabric stiffness was measured according to the AST M D1388-96 standard, Evaluation of wettability was determined according to AATCC test method, D 39-1980, The resistance to tearing was determined according to ASTM procedure D1424-09, Crease recovery angle of the fabrics was determined according to AATCC test method D 67-1957, The Tensile strength and elongation at break in woven fabrics was determined according to ASTM procedure D1682-64-1975. 
The color strength $(\mathrm{K} / \mathrm{S})$ of dyed fabrics was measured by Datacolor Spectrophotometers international v2.3. The color strength ( $\mathrm{K} / \mathrm{S}$ value) was assessed using the Kubelka- Munk equation: $K / S=(1-R) 2 / 2 R \quad$ Emre K. et al. (2004).

Where $\mathrm{K}$ is the sorption coefficient, $\mathrm{R}$ is the reflectance of the dyed fabric and $\mathrm{S}$ is the scattering coefficient. The CIE Lab values were determined for all the samples investigated here. Color fastness to wash of dyed samples was measured by ISO 105-C06-1994. Perspiration fastness was determined according to AATCC Test Method 15-2002 and Colorfastness to light was determined according to AATCC Test Method 16-2004.

\section{Results and discussions:}

Biopolishing consists of a cellulase enzyme treatment to give a partial hydrolysis of cotton; so the short fiber ends are hydrolyzed, leaving the surface of the fibers free and providing a more even look Kan C.W. (2012). The effects of Biopolishing on some physicomechanical properties:

3.1. Effect of biofinishing on fabric Warp and weft sett: The biofinished treatment enhanced the fabric set in both directions. There is a significant improvement in Gabardine more than popline and linen which may be that due to cellulase improves surface morphology, appearance and handle values, which presence of various components. i. e. Cellulase plays a dominating role in altering surface morphology of the fibers and alters the dimensional stability of the fabrics as shown in figure (8). Saravanan D. et al. (2009).

\begin{tabular}{|c|c|c|}
\hline & 100 & Untreated \\
\hline$\xi \vdots$ & $\sigma^{\circ} \quad V$ & Fabric \\
\hline
\end{tabular}

Figure (8): The effect of biofinishing on warp and weft direction set of cotton and linen fabrics

3.2. Effect of biofinishing on Fabrics Weight $\left(\mathrm{g} / \mathrm{m}^{2}\right)$ : It was noticeably observed that weight of the biopolished samples increased than untreated fabrics depending on shrinkage increased and the process conditions employed during the treatment i.e. concentration of cellulase and treatment temperature to a large extent as shown in figure (9). Saravanan D. et al. (2013).

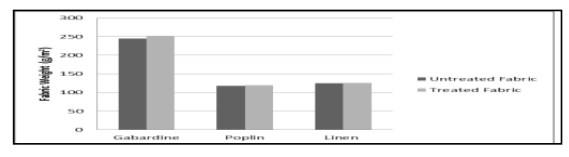

Figure (9): Effect of biopolishing on weight per square of cotton and Linen fabrics.

3.3. Effect of biofinishing on Fabrics stiffness: The stiffness decreased in all types of fabrics as cellulase enzyme which prevents the fuzz and pills of the fabrics leading to an increasing in the smoothness and softness as shown in figure (10). Saravanan D. et al. (2009), Raje, C.R.(2001).

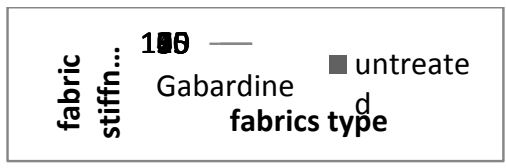

Figure (10): Effect of biopolishing on cotton and linen fabrics stiffness. 
3.4. Effect of biofinishing on Fabrics Wettability: Wettability of the fabrics after biopolishing improves depending upon construction of the fabrics as shown in figure (11). Saravanan D. et al. (2009).

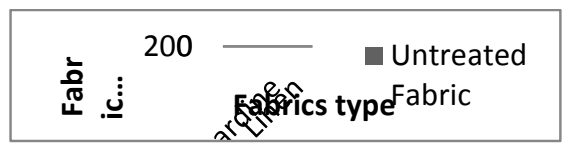

Figure (11): Effect of biopolishing on cotton and linen fabrics wettability.

3.5. Effect of biofinishing on Fabrics tear resistance: Biopolishing with Cellulase treatment lowers the tensile and compressional energy, which essentially means improved handle, also confirmed by decreased bending rigidity and shear rigidity, which further improved in the softness as shown in figure (12).

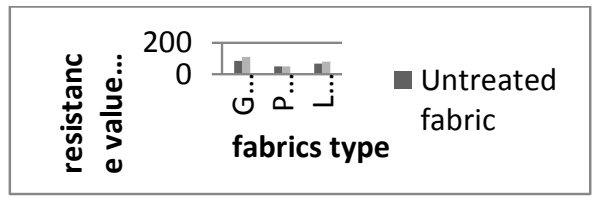

Figure (12): Effect of biopolishing of tear resistance on cotton and linen Fabrics.

3.6. Effect of biofinishing on Fabrics crease recovery angle: Treated samples have increase than untreated fabrics due to the biopolishing enhance the fabric crease recovery due to fabrics become less stiff and easier to stretch and looser in structure as shown in figure (13).

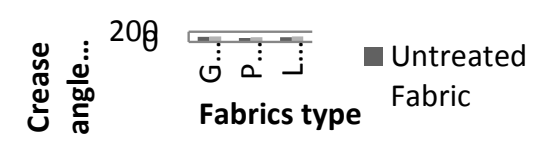

Figure (13): Effect of biopolishing of crease recovery on cotton and linen fabrics.

3.7. Effect of biofinishing on Fabrics Tensile Strength and Elongation: Cellulase enzymes optimize the surface properties of the fabric, but decrease in tensile strength as shown in figure (14).

\begin{tabular}{|c|c|c|}
\hline & 200 & \\
\hline 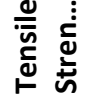 & $\begin{array}{r}\text { Gabardine } \\
\text { Fabric }\end{array}$ & $\begin{array}{l}\text { Untreate } \\
\text { ty Fabric } \\
\text { type }\end{array}$ \\
\hline
\end{tabular}

Figure (14): Effect of biopolishing on tensile strength in warp and weft of cotton and linen fabrics.

There are increases in treated fabrics values due to using enzymes that enhance the elongation as shown in figure (15). Bio-polishing can be applied to the fabric to remove the pills and fuzz from fabric surface, to reduce the tendency of pilling, to improve the smoothness, drape, flexibility and luster. Nilgun $\mathbf{0}$. et al. (2003). 


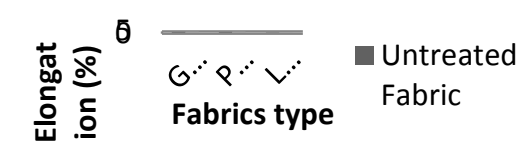

Figure (15): Effect of biopolishing on elongation in cotton and linen fabrics.

\subsection{Reactive dyeing of biopolished fabrics:}

The color strength of fabrics dyed after cellulase treatment was improved which may be due to the removal of protruding fibers that otherwise would decrease the scattering coefficient, which depends on degree of polymerization, ratio of amorphous to crystalline regions, swellability, accessibility, chemical reactivity, surface morphology and affinity for dyes as shown in figures $(16,17,18,19)$. Saravanan D. et al.(2009).

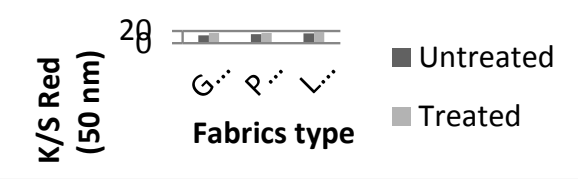

Figure (16): Effect of biopolishing on color strength (k/s) using ME ${ }^{\circ}$ Red ME4BL.

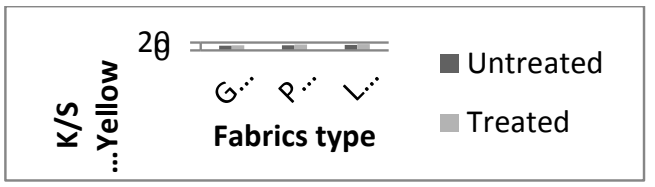

Figure (17): Effect of biopolishing on color strength (k/s) using Jakofix ${ }^{\circledR}$ Yellow MERL.

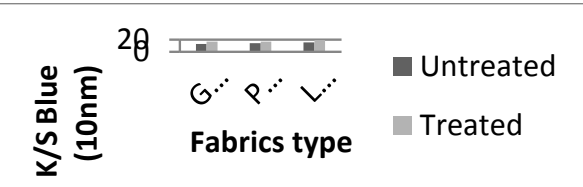

Figure (18): Effect of biopolishing on color strength (k/s) using Drimaren Blue CLBR.

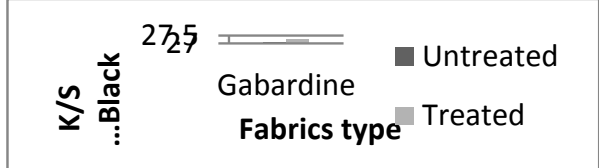

Figure (19): Effect of biopolishing on color strength (k/s) using Remazol ${ }^{\circ}$ Black B 


\subsection{Designs and products:}

\subsubsection{Design (1):}

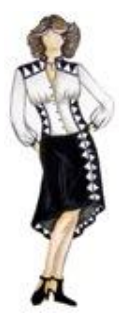

Figure (20): design (1)

This design is suitable for hotel reception. Longitudinal lines with under chest cut added femininity to Model. The contrast in colors is appropriate fashion renewable. It printed with decorative triangles inspired from Nubian walls of the house with modern motifs as shown in figure (20).

\subsubsection{Product (1):}

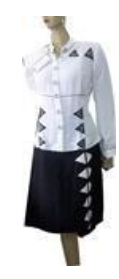

Figure (21): product (1).

Fabrics: $\quad$ Linen for blouse and Gabardine for skirt

Techniques: $\quad$ 1. Stencil printing triangles with foam printing in skirt.

2. Embroidery stitches (Chain Stitches) on front, collar and cuffs.

Dyes: $\quad$ Remazol ${ }^{\circ}$ Black B as shown in figure (21).

\subsubsection{Design (2):}

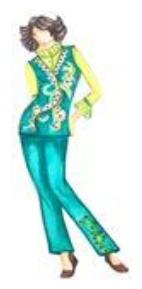

Figure (22): design (2)

This design is suitable for hotel Human resource. It has asymmetry curve lines inspired from the Nubian henna with beautiful creative reliefs. It embroidered in decorative design inspired from Nubian Henna which showed the spirit of Nubian art as shown in figure (22). 


\subsubsection{Product (2):}

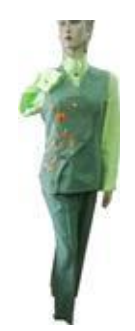

Figure (23): product (2).

Fabrics: $\quad$ Linen for blouse and Gabardine for jacket and trouser.

Techniques: Embroidery stitches: (Chain - Stem - Zigzag - Satin- Chained Feather Bullion) on jacket and trousers inspired from Nubian Henna design.

Dyes: $\quad$ Jakofix Yellow MERL and Drimaren Blue CLBR as shown in figure (23).

\subsubsection{Design (3):}

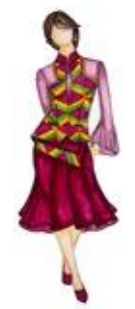

Figure (24): design (3)

This design is suitable for front office. A rhythm wide zigzag lines with different light colors make smoothness of eye movements. This design inspired from fascinated patterns on handicrafts in colored zigzag with new fashion artistic touch, it embroidered in decorative line as shown in figure (24).

\subsubsection{Product (3):}

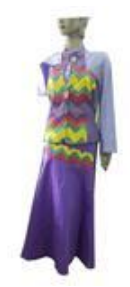

Figure (24): product (3).

Fabrics: $\quad$ Poplin for blouse and Gabardine for jacket and skirt.

Techniques: 1- $\quad$ Stencil printing zigzag on jacket and skirt.

2- Embroidery stitches (Chain) on sleeve and skirt.

Dyes: $\quad$ ME $\quad$ Red ME4BL, Jakofix ${ }^{\oplus}$ Yellow MERL and Drimaren ${ }^{\bullet}$ Blue CLBR as shown in figure (24). 


\subsubsection{Design (4):}

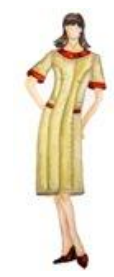

Figure (25): design (4)

This design is suitable for Housekeeper Manager; it has longitudinal lines with fashionable touch, it printed with decorative flowers inspired from Nubian art on walls of house with modern motifs and embroidered on collar and pockets as shown in figure (25).

\subsubsection{Product (4):}

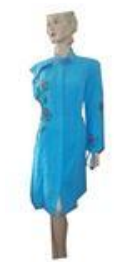

Figure (26): product (4).

Fabrics: Linen for all dress parts.

Techniques: 1- Stencil printing flowers.

2- Embroidery stitches (Herringbone) on collar and pockets

Dyes: $\quad$ ME $\quad$ Red ME4BL, Jakofix Yellow MERL and Drimaren Blue CLBR as shown in figure (26).

\subsubsection{Design (5):}

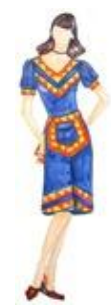

Figure (27): design (5)

This design is suitable for Housekeeper, diagonal colored lines used inspired from Nubian handicrafts art. It printed with decorative triangles inspired from Nubian art on with modern motifs. It embroidered on apron with simple stitches as shown in figure (27). 


\subsubsection{Product (5):}

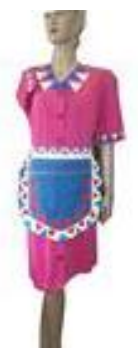

Figure (28): product (5).

Fabrics: $\quad$ Gabardine for all dress parts and apron.

Techniques: 1- Stencil printing with triangles on cuff, front neck and apron.

2- Embroidery stitches (Chevron Stitches) on apron.

Dyes: $\quad$ ME $\quad$ Red ME4BL, Jakofix Yellow MERL and Drimaren Blue CLBR as shown in figure (28).

\subsubsection{Design (6):}

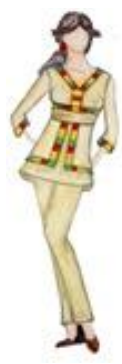

Figure (29): design (6)

This design is suitable for Spa, it has attractive vertical and horizontal lines, it printed with decorative design inspired from the walls of the house were decorated with ornaments and flowers with modern motifs. It embroidered with simple and pretty stitches as shown in figure (29).

\subsubsection{Product (6):}

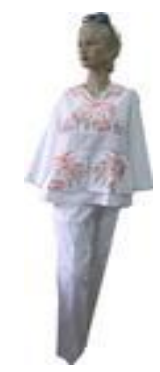

Figure (30): product (6).

Fabrics: $\quad$ Poplin for blouse and Gabardine for trousers. 
Techniques: $\quad 1-\quad$ Stencil printing decorative design on blouse and trousers.

2- Embroidery stitches (Chain - Chain Feather) on blouse and trousers.

Dyes: $\quad$ ME $\quad$ Red ME4BL, Jakofix Yellow MERL and Drimaren Blue CLBR as shown in figure (30).

3.9.13. Design (7):

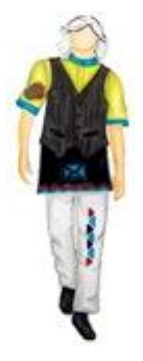

Figure (31): design (7)

This design is suitable for restaurant, circles and triangles lines used inspired from Nubian handicrafts art. It printed with decorative circles and triangles inspired from Nubian handicrafts art with modern motifs on back shirt and apron as shown in figure (31).

\subsubsection{Product (7):}

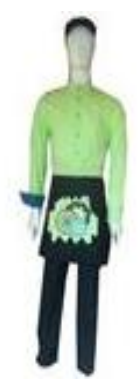

Figure (32): product (7).

Fabrics: $\quad$ Poplin for shirt and Gabardine for trousers and apron.

Techniques: Stencil printing circles and triangles design on back shirt and apron.

Dyes: $\quad M E^{\circ}$ Red ME4BL, Jakofix $\quad$ Yellow MERL, Drimaren ${ }^{\bullet}$ Blue CLBR and Remazol Black $B$ as shown in figure (32).

\subsubsection{Design (8):}

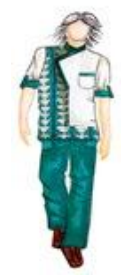

Figure (33): design (8) 
This design is suitable for chef it has attractive diagonal closet lines making eye moving around. It printed with decorative Nubian dashed triangle design on jacket, trouser and cap. It inspired from Nubian handicrafts art with modern motifs as shown in figure (33).

\subsubsection{Product (8):}

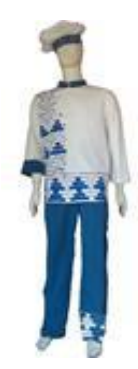

Figure (34): product (8).

Fabrics: Gabardine for jacket, trousers and bonnet.

Techniques: Stencil printing Nubian dashed triangles.

Dyes: $\quad$ Drimaren $\quad$ Blue CLBR as shown in figure (34).

\subsubsection{Design (9):}

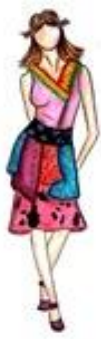

Figure (35): design (9).

This design is suitable for restaurant, its unconventional design it has more attractive asymmetry lines. It printed with decorative design inspired from the walls of the house were decorated with ornaments and flowers, henna and handicrafts with modern motifs, It embroidered with simple and pretty stitches as shown in figure (35).

\subsubsection{Product (9)}

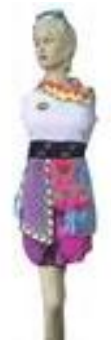

Figure (36): product (9).

Fabrics: $\quad$ Remaining parts of fabrics linen, poplin and Gabardine.

Techniques: 1 . Stencil printing from different used designs.

2. Embroidery stitches (Stem Stitches) on upper part of dress. 
3. Tie and dye on lower part of dress.

Dyes: $\quad$ ME ${ }^{\oplus}$ Red ME4BL, Jakofix ${ }^{\oplus}$ Yellow MERL, Drimaren Blue CLBR and Remazol ${ }^{\bullet}$ Black $B$ as shown in figure (36)

\section{Conclusion}

There are some linked things inspired from Nubia art elements such as design motifs, dye colors, printing, and fabrics types. Biopolishing with cellulase enzyme improved quality and functionality of the products to suit the nature of hotel uniform in terms of comfort, movement, working and the weather to satisfy the wearer.

\section{References:}

Anon J., Dyes, in Cotton Dyeing and Finishing, A Technical Guide, Cotton Incorporated, Cary, NC, 28-132, (1996).

Diana K., and Aleya A., Space, Color and Quality of Life in a Nubian Environment, International Journal of Architectural Research, 6, 1, 77-89, (2012).

Elise D.C., Computation and Technology as Expressive Elements of Fashion, M.S Thesis, Massachusetts Institute of Technology, (2000).

Emberling G., Nubia Ancient Kingdoms of Africa, New York Institute for the study of the ancient world, 8. (2011).

Emre K., Merih O., and Sariisik, Scouring of Cotton with Cellulases, Pectinases and Proteases, Fibers and Textiles in Eastern Europe, 12, 3 ,47, (2004).

Kan C.W., and Law K.P., A Study of Reactive Dyeing and Enzymatic Treatment on Some Properties of Cotton, RMUTP International Conference, Textiles \& Fashion, Bangkok Thailand, 3-4, (2012).

Kiro M., Application of Enzymes in the Textile industry, International Congress Engineering, Ecology and Materials in the Processing Industry, Jahorina, (2011).

Nelson K., and Bowen J., The Effect of Employee Uniforms on Employee Satisfaction, Cornell Hotel and Restaurant Administration Quarterly 41, 2, 86-95(2000).

Nilgun O., Esen O. and Tulin O., Effects of Enzymatic Treatment on Various Spun Yarn Fabrics, fibers and textiles, Eastern Europe,11,4, 43,(2003).

Raje, C. R., Gurjar M., and Kawlekar S.R., Finishing of Cotton Fabrics with Cellulase Enzymes, Indian Textile Journal, 112, 37-41, (2001).

Ramakrishnan A., Mohammad S.M., and Mala R., Application of Cellulases from an Alkalothermophilic Thermomonospora sp. in Biopolishing of Denim., Wiley Inter Science, biotechnology and bioengineering, 96, 1, (2007)

Robison J., Uniform Appeal. Casino Journal 18, 2, 34-36, (2005).

Samiha A.K., Nubian Ceremonial Life: Studies in Islamic Syncretism and Cultural Change book, Egypt, (2012). 
Saravanan D., Lakshmi S. N., Senthil R.K., and Vasanthi N.S., Biopolishing of Cotton Fabric with Fungual Cellulase and its Effect on the Morphology of Cotton Fibers., Indian J. Fiber and textile Res, 38, 156- 160,(2013).

Saravanan D., Vasanthi N.S., and Ramachandran T., A Review on Influential Behavior of Biopolishing on Dyeability and Certain Physico-mechanical Properties of Cotton Fabrics, Carbohydrate Polymers, 76,1-7, (2009). 


\section{الملخص العربي}

\section{تصميمات مبتكرة مستوحاة من البيئة المصرية للزى الفندقى}

\section{آيات ابراهيم محمد ، مها محمدى طه العدوى ، رحاب محمود قطب}

قسم اقتصاد منزلى ، كلية البنات للآداب و العلوم و التربية ، جامعة عين شمس، القاهرة ، مصر.

فى هذه الدراسة تم استنباط تصاميم جديدة مستوحاة من الفلكلور النوبى ( البيئة المصرية ) حيث يمكن استخدامها كزى فندقى فى الفنادق المختلفة بغرض تحسين الاداء فى هذه المؤسسات. تم استخدام الاقمشة

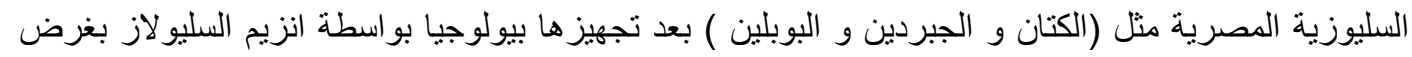

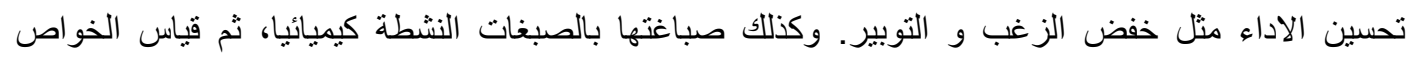
الفيزوميكانيكية لاقمشة المختارة و المجهزة و المصبو غة وكذلك قياس شدة اللون للاقشة المصبو غة. 